\title{
KUMPULAN LESBIAN, GAY, BISEKSUAL DAN TRANSGANDER (LGBT) ANCAMAN TERHADAP KEAMANAN DAN KEHARMONIAN BERAGAMA DI MALAYSIA
}

\author{
Noor Hafizah bt. Mohd Haridi \\ Kolej Universiti Islam Antarabangsa Selangor \\ Email:noorhafizah@kuis.edu.my \\ Norsaleha bt. Mohd Salleh \\ Kolej Universiti Islam Antarabangsa Selangor \\ Email:norsaleha@kuis.edu.my
}

DOI: http:/ / dx.doi.org/ 10.30983/islam_realitas.v2i2.190

\section{Abstract}

Sexual and Gender disorder Issues, which refers to Lesbian, Gay, Bisexual, and Transgender (LGBT) community is not a new issue. Allah has explained about homosexual issues prevailing among the people of Prophet Luth. This paper discusses the related issues (LGBT) by analyzing a collection of aspects of this threat to the security and religious harmony. Various claims have been made by this group in the name of human rights. Symptoms, treatment and disposition opposed to the normal life of a person human system has become a regular affair in the world and especially Malaysia. In fact the case is cultivated in transnational level through United Nation Human Right Convention (UNHRC) and backed by the major countries in tthe world. The symptoms of lesbian, gay, bisexual and transgender (LGBT) bas become accepted way of life by the outside community and now infiltrating in the life of islamic community in Malaysia. These symptoms shall be dammed to ensure public security and religious harmony in Malaysia.

Keywords: Lesbian, Gay, Biseksual dan Transgander (LGBT) community,threat, security and religious harmony in Malaysia

\section{Abstrak}

Permasalahan kecelaruan seksual dan jantina, yang merujuk kepada komuniti Lesbian, Gay, Biseksual. dan Transgender (LGBT) bukan merupakan isu baru. Sebaliknya, Allah swt telah menjelaskan tentang permasalaban homoseksual yang berlaku di kalangan umat Nabi Lut as. Penulisan ini membincangkan isu berkaitan (LGBT) dengan menganalisis dari aspek ancaman kumpulan ini terbadap keamanan dan keharmonian beragama. Pelbagai tuntutan telah dilakukan oleh kumpulan ini atas nama hak asasi manusia. Gejala, perlakuan dan tabiat bertentangan dengan sistem kebidupan normal seseorang manusia telah menjadi suatu perkara yang biasa di dunia amnya dan Malaysia khasnya. Malah perkara ini diperjuang di peringkat antarabangsa menerusi United Nation Human Rigbt Convention (UNHRC) dan disokong oleh negara-negara besar dunia.Gejala lesbian, gay, biseksual dan transgender (LGBT) telah menjadi cara hidup yang diterima oleh masyarakat luar dan kini sedang meresap masuk. ke ruang atmosfera kehidupan masyarakat Islam di Malaysia. Gejala ini wajib dibendung bagi menjamin kemanan dan keharmonian beragama masyarakat di Malaysia.

Kata Kunci: Kumpulan Lesbian, Gay, Biseksual dan Transgander (LGBT) Ancaman, Keamanan Keharmonian, Beragama di Malaysia

\section{Latar Belakang}

Lesbian, Gay, Biseksual, dan

Transgender atau akronimnya sebagai LGBT ini

Noor Hafizah bt. Mohd Haridi \&

Norsaleha bt. Mohd Salleh juga dianggap sebagai satu penyakit mental, kerana telah melawan fitrah. Fitrah kehidupan manusia yang normal ialah hidup berpasangpasangan. Sebagaimana telah diciptakan oleh 
Allah SWT, lelaki pasangannya adalah perempuan, begitu juga dengan haiwan, jantan pasangannya adalah betina, baik pasangannya jahat, cantik pasangannya ialah huduh. Kesimpulannya, setiap makhluk yang diciptakan oleh Allah SWT di muka bumi ini berpasang-pasangan. Ini adalah fitrah setiap ciptaan Yang Maha Esa.

Dalam Rahardjo dan Murtagh Permasalahan kecelaruan seksual dan jantina, yang merujuk kepada komuniti Lesbian, Gay, Biseksual. dan Transgender (LGBT) bukan merupakan isu baru ${ }^{1}$. Sebaliknya, Allah swt telah menjelaskan tentang permasalahan homoseksual yang berlaku di kalangan umat Nabi Luth as Perbuatan homoseksual tersebut jelas merupakan perkara yang keji sebagaimana firmanNya pada ayat 80-84, Surah al-A"raf yang bermaksud :

"Dan Nabi Lut (juga kami utuskan). Ingatlah tatkala dia berkata kepada kaumnya "Patutkah kamu melakukan perbuatan yang keji. yang tidak pernah dilakukan oleh seorang pun daripada penduduk alam ini sebelum kamu? " Sesungguhnya kamu mendatangi lelaki untuk memuaskan nafsu syahwat kamu dengan meninggalkan perempuan, bahkan kamu inhi ddalab' kaunr yang melampaui batas". Dan tiada jawapan oleh kaumnya melainkan mereka beerkata "Usirlah merka (Nabi Luth dan pengikutnya yang taat) dari bandar kamu ini. sesungguhnya mereka adalah orangorang yang (mendakwa) mensucikan diri. Maka kami selamatkkan dia dan ahlinya (keluarganya dan pengikutnya) melainkan isterinya. adalah dia tergolong dalam orang-orang yang dibinasakan. Dan Kami telah menghujani mereka dengan hujan (batu yang

1 Rahardjo, Wahyu, "Sikap Akan Respon terhadap Identitas Sosial Negatif dan Pengungkapan Orientasi Seks Pada Gay", Jurnal Ilmiah Psikologi,1.1 2011, h. 20. Lihat juga Murtagh, Ben, "Gay, Lesbi and Waria Audiences in Indonesia: Watching Homosexuality on Screen", Indonesia and the Malay World, 39.115, 2011, h. 391-415.

Noor Hafizah bt. Mohd Haridi \& Norsaleha bt. Mohd Salleh membinaskurn). Oleh itu. lihatlah bagaimana akibat orang-orang yang melakukan kesalahan".

Ayat di atas jelas menggambarkan perilaku umat Nabi Lut a.s yang mengalami masalah kecelaruan seks apabila memiliki kecenderungan untuk melakukan hubungan intim dengan kaum sejenis iaitu lelaki bersama lelaki. Orientasi seksual yang dilakukan sesama pasangan sejenis atau homoseksual disebut di dalam hadith dengan istilah liwat (homoseksual) dan al-sibaq (lesbian). Di dalam ayat al-Quran tersebut. Allah menggambarkan azab yang menimpa ke atas kaum Nabi Lut a.s iaitu Kaum Sodom dan Kaum Amoro, suatu daerah di negeri Syam.

Malaysia dikejutkan dengan isu gerakan kemanusian yang diperjuangkan kebebasannya di Malaysia. Sebagaimana penelitian Renn, isu gerakan kebebasan kemanusian ini menuntut agar golongan Lesbian, Gay, Biseksual dan Transeksual (LGBT) diiktiraf di Negara ini ${ }^{2}$. Usaha ini diperjuangkan oleh salah seorang tokoh Malaysia Ambiga Sreevanasan. Dalam penjelasan Ryan, Ambiga Sreevanasan, atau wajar digelar wanita besi, atas semangatnya berjuang menentang arus. Beliau mendedikasikan hidupnya untuk memperjuangkan hakasasi manusia. Untuk itu, beliau telah dikritik dan diprovokasi pelbagai pihak tetapi beliau berjaya meraih penghormatan dan menerima penghargaan dari berbagai pihak juga. Atas kesungguhan beliau memperjuangkan pendiriannya, beliau telah menerima anugerah International Women of Courage pada tahun 2009 oleh kerajaan Amerika ${ }^{3}$.

${ }^{2}$ Renn, Kristen A., "LGBT Student Leaders and Queer Activists: Identities of Lesbian, Gay, Bisexual, Transgender, and Queer Identified College Student Leaders and Activists", Journal of College Student Development, 48.3, 2007, h. 311-330.

${ }^{3}$ Ryan, Caitlin, et al., "Family Acceptance in Adolescence and The Health of LGBT Young 
Beliau juga menerima anugerah tertinggi Perancis Chevalier de Legion d'Honneur (Knight of the Legion of Honour) daripada kerajaan Perancis. Pada tahun 2012, beliau membuka sejarah baru di Malaysia apabila dengan lantang menyuarakan sokongan beliau ke atas golongan LGBT di Malaysia. Perjuangan beliau ini sememangnya bertentangan dengan nilai, etika dan keagamaan yang diamalkan di Malaysia. Malaysia merupakan sebuah Negara yang mengamalkan sistem pemerintahan demokrasi berpelembagaan dan menjadikan Agama Islam sebagai Agama rasmi. Oleh itu perjuangan Ambiga bertentangan dengan ajaran Islam dan tidak seharusnya diteruskan kerana ianya menganggu sentimen keagamaan di Malaysia ${ }^{4}$.

Sokongan terhadap hak asasi kumpulan LGBT ini turut disuarakan oleh kumpulan G25. Yang menyuarakan hak terhadap kumpulan ini. Kumpulan ini melalui jurucakapnya Dato' Farida Ariffin dengan lantang menyurakan hak kebebasan terhadap kumpulan ini ${ }^{5}$. Tulisan ini akan mengungkap perihal fenomena LGBT di Malaysia serta dampaknya terhadap keamanan dan keharmonisan hidup beragama.

\section{Definisi LGBT}

Definisi LGBT dalam Marbawi dan Tim Encyclopedia adalah singkatan bagi lesbian, gay, biseksual dan transeksual ${ }^{6}$. Dalam Mastuti, sesetengah pihak menambah akronim ini

Adults", Journal of Child and Adolescent Psychiatric Nursing, 23.4, 2010, h. 205-213.

${ }^{4}$ Haridi, Noor Hafizah bt. Mohd, "Metodologi Dakwah Persatuan Amal Firdausi (PAFI) terhadap Kumpulan LGBT", Laporan Geran Penyelidikan KUIS, 2015, h. 20

${ }^{5}$ Renn, Kristen A., "LGBT and Queer Research In Higher Education: The State and Status of The Field", Educational Researcher, 39.2, 2010, h. 132-141.

${ }^{6}$ Marbawi, Muhammad Idris Abdul Rauf, Kamus Idris Marbawi Arab-Melayu (Kuala Lumpur:Darul Fikir, 2006), h. 12. dan Tim, The Encyclopaedia of Islam New Edition. (Netherland: Reiden E.J.Brill, Wiley-Blackwell, 1983), h. 21.

Noor Hafizah bt. Mohd Haridi \& Norsaleha bt. Mohd Salleh kepada LGBTIQ, di mana I untuk intersex dan Q untuk queer ${ }^{7}$. Menurut Blanch Consulting dalam Mastuti dan Perry, lesbian didefinisikan sebagai seorang perempuan yang tertarik secara emosional, seksual, fizikal terhadap perempuan lain ${ }^{8}$. Ia juga bermaksud hubungan songsang dan luar tabie'e diantara wanita dan wanita. Di Malaysia, perbuatan ini dianggap sebagai salah satu kesalahan jenayah yang boleh dikenakan hukuman yang setimpal dengan perbuatan tersebut. Jika di dalam Islam, lesbian ini lebih dikenali dengan panggilan musahaqah.

Dalam Evans, Gay dikenali sebagai homoseksual didefinisikan sebagai gololongan lelaki yang mempunyai tarikan seksual terhadap kaum sejenisnya. Gay juga membawa pengertian yang lebih kurang sama dengan lesbian iaitu hubungan songsang dan luar tabie'e, akan tetapi gejala gay ini dipraktikkan diantara lelaki dan lelaki'. Istilah gay juga telah diperbaharui dalam kolompok mereka dengan man sex with man(MSM).

Biseksual bermaksud amalan persetubuhan bebas antara pasangan lelaki dan perempuan. Dalam Hamdi, pasangan yang dinyatakan di sini termasuklah pasangan yang mengamalkan persetubuhan semasa sebelum berkahwin dan semasa sudah berkahwin juga iaitu dengan menukar pasangan berkahwin dengan orang lain ${ }^{10}$.

${ }^{7}$ Mastuti, Ratri Endah, Rachmad Djati Winarno, and Lita Widyo Hastuti, "Pembentukan Identitas Orientasi Seksual pada Remaja Gay", Prediksi, 1.2 2012, h. 194

${ }^{8}$ Perry N. Halkitis et.al, "The Meanings and The Manifestations of Religion and Spirituality Among Lesbain, Bisexsual and Transgender", Journal Adult Development, 16.2, 2009, h. 20

${ }^{9}$ Evans, Nancy J., "The Impact of an LGBT Safe Zone Project on Campus Climate", Journal of College Student Development, 2002, h. 32

${ }^{10}$ Hamdi, Ahmad Zainul, and Dédé Oetomo Tonny, "Tak Pernah Berhenti Bercinta: Studi Tentang Seksualitas Sepuluh ODHIV di Surabaya", Jurnal Gandrung, 1.2, 2010, h. 73-102. 
Transeksual atau Mukhannath ialah seseorang lelaki atau perempuan yang berperasaan dan berpenampilan sebagai anggota jantina yang satu lagi, dan kadangkadang menukar organ jantinanya melalui pembedahan. Secara umumnya, semua takrifan mengenai LGBT adalah berkaitan dengan amalan homoseksual. Manakala golongan transeksual perlu dilihat secara berasingan berdasarkan situasi tertentu seperti khuntha, mak nyah, dan pengkid. Sebutan penuh "LGBT" adalah merujuk kepada Gerakan Homoseksual yang mendedahkan mereka kepada masalah pelacuran/homoseksualiti dan jangkitan HIV/AIDS, sifilis dan sebagainya.

\section{LGBT di Malaysia}

Peringkat awal kewujudan golongan LGBT di Malaysia bermula dengan kewujudan pondan dan mak nyah sekitar tahun 1980-an. Persidangan Majlis Raja-Raja kali ke- 126 pada 13 Disember 1989 telah memfatwakan LGBT sebagai perlakuan yang haram untuk diamalkan sebagai gaya hidup. Rentetan dari pewartaan fatwa ini telah menghalang manamana individu membuat permohonan menukar jantina pada dokumen pengenalan diri. Masyarakat Malaysia sangat sensitif dengan gaya hidup yang menyalahi tuntutan agama dan tatasusila budaya timur apatah lagi dengan perlakuan yang menyalahi tabi'e manusia.Oleh itu, golongan LGBT mendapat kecaman hebat di kalangan masyarakat Islam Malaysia ${ }^{11}$.

Namun, merujuk kepada statistik tangkapan oleh Pegawai Penguatkuasa Agama seluruh Malaysia yang semakin meningkat, jelas menunjukkan bahawasanya perlakuan dan gaya hidup LGBT ini tetap berkembang dan menjadi semakin kompleks. Gerakan LGBT merupakan gerakan diskriminasi bentuk baru

\footnotetext{
${ }^{11}$ Haridi, Noor Hafizah bt. Mohd, "Metodologi Dakwah Pertsatuan Amal Firdausi(PAFI) terhadap Kumpulan LGBT'”..., h. 15

Noor Hafizah bt. Mohd Haridi \&

Norsaleha bt. Mohd Salleh
}

atas nama hak asasi ${ }^{12}$. Mereka menggunakan Hak Asasi Manusia (HAM) untuk mempertahankan perbuatan mereka.Tindakan golongan ini bukan sahaja mencerca kesucian agama Islam dan perundangan Malaysia, malah menggugat ketenteraman awam dan keamanan agama. Gerakan LGBT merupakan gerakan diskriminasi bentuk baru atas nama hak asasi. Mereka menggunakan Hak Asasi Manusia (HAM) untuk mempertahankan perbuatan mereka. Tindakan golongan ini bukan sahaja mencerca kesucian agama Islam dan perundangan Malaysia, malah menggugat ketenteraman awam dan keamanan agama ${ }^{13}$.

Oleh kerana bertentangan dengan orientasi seks yang normal, LGBT adalah kumpulan minoriti dalam masyarakat.Walaupun begitu, kumpulan ini giat mempromosikan dan menzahirkan diri mereka dalam usaha untuk menuntut hak-hak yang sewajarnya dalam kehidupan sosial. Senario dalam kehidupan masyarakat moden juga memperlihatkan bahawa mereka yang menyokong pergerakan menuntut hak-hak homoseksual adalah mereka yang diiktiraf sebagai pejuang hak asasi manusia dan sebaliknya. Pada dasarnya, kelompok LGBT di seluruh dunia menuntut 8 perkara utama, iaitu 1) aktiviti seks sesama jantina (tidak mengambil kira soal haram atau halal), 2) pengiktirafan terhadap hubungan sesama sejenis atau berlainan jenis, 3)perkahwinan sesama jantina, 4) pengambilan anak angkat, 5) membenarkan gay untuk berkhidmat dalam tentera, 6) membenarkan lesbian untuk berkhidmat dalam tentera, 7) anti diskriminasi berdasarkan orientasi seksual, 8)

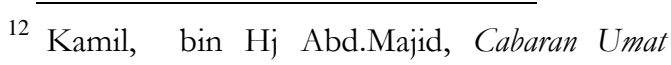
Dewasa Ini: Suatu Penyelesaian Menurut Islam. (Kuala Lumpur: Fakulti Usuluddin Akademi Islam Universiti Malaya, 1988).

${ }^{13}$ Zakaria, Stapa, Masyarakat Islam dan Isu Semasa, (Kuala Lumpur: YADIM, 1994), h. 32. 
memperjuangkan undang-undang untuk identiti gender dan ekspresi gender ${ }^{14}$.

Pertubuhan dalam studi Kosciw, LGBT yang terbesar di dunia ialah International Lesbian, Gay, Bisexual, Trans and Intersex Association (ILGA) ${ }^{15}$. ILGA merupakan pertubuhan LGBT di seluruh dunia yang mempunyai matlamat yang sama. Pertubuhanpertubuhan LGBT di seluruh dunia aktif memperjuangkan hak kumpulan mereka dan mengumpulkan ahli-ahlinya. Di Asia Tenggara menurut Veritisia seperti di Singapura, kumpulan LGBT menubuhkan kumpulan yang bernama People Like Us (PLU) untuk menguruskan aktiviti-aktiviti mereka manakala di Malaysia kumpulan Seksualiti Merdeka dilihat sebagai organisasi yang giat mempromosikan agenda LGBT $^{16}$.

Seksualiti Merdeka sentiasa berusaha untuk mengubah kehidupan sosial serta penerimaan undang-undang berkenaan dengan kepelbagaian orientasi seksual di Malaysia.Hal ini adalah merujuk kepada arena antarabangsa yang memberikan hak kesamaan dan mengkritik hukuman undang-undang terhadap kumpulan minoriti iaitu mereka yang mempunyai orientasi seks yang tidak dominan dan berbeza dengan kumpulan majoriti. Kerajaan Malaysia dalam kenyataannya menjelaskan bahawa pihak berkuasa serius dalam usaha dan ingin menangani gejala LGBT berikutan terdapat usaha untuk menuntut agar golongan lesbian, gay, bi-

$14 \overline{\text { Azmi, Kamal Abd. Rahman, Profil Masayarakat }}$ Melayu Malaysia di Media Sosial Yang Mempromosikan Agenda LGBT dalam Isu-Isu Semasa Media dan Dakwah (Kuala Lumpur: Universiti Malaya: 2005), h. 25.

15 Kosciw, Joseph G., et al., "The Effect of Negative School Climate on Academic Outcomes for LGBT Youth and The Role of In-School Supports", Journal of School Violence, 12.1, 2013, h. 45-63.

16 Veritasia, Mytha Eliva, "Pengungkapan Informasi Privat tentang Identitas Seksual Seorang Gay kepada Orang Lain", Commonline Departemen Komunikasi, 4.2, 2015, h. 20

Noor Hafizah bt. Mohd Haridi \&

Norsaleha bt. Mohd Salleh seksual dan tran-seksual (LGBT) diiktiraf pada tahun $2012^{17}$.

\section{Islam Sebagai Cara Hidup Yang Amat Lengkap dan Sempurna}

Perkataan Islam mengandungi dua makna yang dominan dan berkaitan antara satu sama lain iaitu penyerahan aslama dan keamanan salama ${ }^{18}$. Islam berasal dari perkataan Arab yang bermaksud aman, damai, selamat dan sejahtera ${ }^{19}$. Islam bermaksud penyerahan diri kepada Allah s.w.t. dengan penuh keikhlasan hati dan mengesakan Allah s.w.t., sujud, tunduk, patuh serta beriman dengan dasar yang telah ditetapkan oleh Allah s.w.t. sebagai satu sistem kehidupan yang lengkap iaitu penerimaan sepenuhnya dari sudut keyakinan dalam hati, ucapan dengan mulut dan dipraktikkan dengan tindakan atau tingkah laku dalam kehidupan ${ }^{20}$.

Dalam Rozi, ajaran Islam merupakan agama yang akan menyampaikan manusia kepada desnitasi yang pasti dengan selamat. Setiap manusia yang menjalani perjalanan hidupnya di atas jalan Islam pasti akan menemui jalan yang lurus dan sejahtera. Kejahteraan yang dimaksudkan di sini ialah kehidupan yang berteraskan kepada keImanan dan ketaqwaan kepada Allah swt dan menjadikan Islam sebagai cara hidup yang sempurna ${ }^{21}$.

Di antara tujuan perjuangan Islam ialah mencari keamanan dan kesejahteraan untuk semua manusia. Sebagaiman firman Allah swt

${ }^{17}$ Haridi, Noor Hafizah bt. Moh, "Metodologi Dakwah Pertsatuan Amal Firdausi (PAFI) terhadap Kumpulan LGBT'”..., h. 15.

18 Ibn Manzur, Lisan al-'Arab (Beirut: Dar alTurath al-'Arabi, 1992), h. 54.

${ }^{19}$ Rahman, Afzalur, Islam Ideology and The Way of Life (Kuala Lumpur: Pustaka Hayathi, 1995), h. 43.

${ }^{20}$ Hawwa, Sa'id, al-Islam (Beirut: Dar al-Shuruq, 1979), h. 43.

21 Rozi, Syafwan, "Tracking on Moderate Muslim in Indonesia", Turast: Jurnal Penelitian dan Pengabdian (e-Journal), 2.1, 2016, h. 64-82. 
dalam Surah al-Baqarah, 2:208 yang bermaksud:

Maksudnya: "Wahai orang-orang Yang beriman! masuklah kamu ke Dalam agama Islam (dengan mematuhi) Segala hukum-hukumnya; dan janganlah kamu menurut jejak langkah Syaitan; Sesungguhnya Syaitan itu musuh bagi kamu Yang terang nyata"

Dan tujuan perjuangan Rasulullah saw untuk menggalakkan semangat kerjasama, keamanan di antara seluruh umat manusia. Sebagaimana firman Allah swt dalam surah (alHujurat, 49:13) maksudnya:

Maksudnya: Wahai umat manusia! Sesungguhnya Kami telah menciptakan kamu dari lelaki dan perempuan, dan Kami telah menjadikan kamu berbagai bangsa dan bersuku puak, supaya kamu berkenal-kenalan (dan beramah mesra antara satu Dengan Yang lain). Sesungguhnya semulia-mulia kamu di sisi Allah ialah orang Yang lebih taqwanya di antara kamu, (bukan Yang lebih keturunan atau bangsanya). Sesungguhnya Allah Maha Mengetahui, lagi Maha mendalam pengetahuannya (akan keadaan dan amalan kamu).

\section{LGBT Ancama Terhadap Agama}

Masyarakat Malaysia sangat sensitif dengan gaya hidup yang menyalahi tuntutan agama dan tata susila budaya Timur apatah lagi dengan perlakuan yang menyalahi tabi'e manusia. Oleh itu, golongan LGBT mendapat kecaman hebat di kalangan masyarakat Islam Malaysia. Namun, merujuk kepada statistic tangkapan oleh Pegawai Penguat kuasa Agama seluruh Malaysia yang semakin meningkat, jelas menunjukkan bahawasanya perlakuan dan gaya hidup LGBT ini tetap berkembang dan menjadi semakin kompleks ${ }^{22}$.

Asalnya, hubungan sesama jenis tidak diterima langsung oleh masyarakat, tetapi atas

${ }^{22}$ Haridi, Noor Hafizah bt. Mohd, "Metodologi Dakwah Pertsatuan Amal Firdausi(PAFI) terhadap kumpulan LGBT....., h. 32

Noor Hafizah bt. Mohd Haridi \&

Norsaleha bt. Mohd Salleh desakan dan tuntutan hak asasi manusia, Barat melalui Pertubuhan Bangsa-Bangsa Bersatu (PBB) telah menerima serta mengiktiraf golongan ini. Artikel 1 Perisytiharaan Sejagat Hak Asasi Manusia (UDHR 1948) telah ditafsir begitu longgar oleh Barat di mana ia meliputi segenap hubungan manusia. Desakan itu dilihat dalam kebebasan manusia meliputi hak asasi manusia, orientasi seks dan identiti gender (SOGI) yang didasarkan oleh satu deklarasi tajaan Perancis-Belanda yang dikemukakan oleh Argentina pada perhimpunan PBB, 19 Disember 2008.

Tuntutan (SOGI) ini juga ditolak oleh Malaysia bersama Negara Islam lain yang membabitkan hak LGBT di Majlis Hak Asasi Manusia di Geneva pada 14 Februari 2012. Tuntutan ini juga turut dibantah oleh Negaranegara Islam di bawah Pertubuhan NegaraNegara Islam (OIC).

Dalam konteks perundangan di Malaysia. Perlakuan yang dilakukan oleh kumpulan LGBT merupakan suatu kesalahan di bawah undang-undangKesalahan Jenayah Syariah negeri-negeri, peruntukan adalah merangkumi semua peruntukan yang ada di dalam akta, enakmendan Ordinan di negerinegeri seluruh Malaysia, yaitu; 1) Liwat; 2) Lelaki berlagak seperti perempuan; 3) Perempuan berlagak seperti lelaki; 4) Musahaqah; 4) Perhubungan jenis luar tabi'at; 5) Pondan; dan, 7) Hubungan jenis antara orang yang sama jantina.

Peruntukan-peruntukan di atas adalah merangkumi semua peruntukan yang ada di dalam akta, enakmendan Ordinan di negerinegeri seluruh Malaysia.

Amalan dan cara hidup kumpulan LGBT ini jelasnya bertentangan dengan Islam merangkumi aspek akidah, ibadah dan akhlak. Kumpulan ini jelasnya mempunyai mengaruh dan pengikut. Sikap masyarakat umum yang sentiasa meletakkan "stigma" dan judge mental terhadap kumpulan ini merupakan salah satu 
faktor kumpulan ini membentuk komuniti tersendiri. Hasil penyelidikan yang dilakukan mendapati terdapat kumpulan LGBT seperti Gay atau MSM (men sex with man) mempunyai "app” tersendiri untuk berinteraksi sesama kumpulan mereka. Terdapat juga kumpulan transgender atau mak nyah yang telah melakukan pembedahan menukar alat kelamin berkahwin dan mengambil anak angkat serta hidup sebagai pasangan suami isteri. Malah, terdapat juga kumpulan LGBT terutama transgender yang murtad dan mengambil keputusan membunuh diri.

Gejala yang berlaku dalam kumpulan LGBT ini jika tidak ditangani secar serius akan memberi impak dan cabaran dan tentangan terhadap Islam khusunya dalam aspek maqasid (matlamat). Elemen ini merangkumi aspek memelihara agama, akal, jiwa, keturunan (maruah diri) dan harta.

Bagi menangani masalah yang berlaku dalam kalangan kumpulan LGBT ini, setiap pihak mestilah memandang serius. Isu ini bukanlah satu isu yang perlu di viral di media sosial. Bahkan, ia mestilah ditangani dengan penuh hikmah. Kumpulan ini mestilah didekati dan disantuni dalam ertikata mereka tidak boleh terus dibiarkan melalui kehidupan tanpa mendapat perhatian dan sokongan mana-mana pihak. Badan kerajaan, bukan kerajaan mahupun individu Muslim disarankan mengatur stategi dan bersatu bagi membantu mengatasi masalah ini. Kecelerauan dan konflik gender dalam kalangan kumpulan LGBT ini mestilah ditangani seawal yang mungkin. Perkara dan usaha ini penting bagi memastikan kumpulan ini sedar bahawa apa yang dilakukan oleh mereka bukanlah fitrah kehidupan mereka. Malah, mereka sendiri dapat mengubah cara hidup berlandaskan cara hidup Islam yang berteraskan kepada alQuran dan al-Sunnah.

\section{Kesimpulan}

Noor Hafizah bt. Mohd Haridi \& Norsaleha bt. Mohd Salleh
Berdasarkan kenyataan yang telah dikemukakan, menjelaskan kepada kita betapa manusia kini berhadapan dengan kes LGBT sebuah krisis yang amat besar dan kritikal dalam kehidupan mereka iaitu krisis yang melibatkan identiti diri dan tamadun mereka. Bilamana manusia, menurut Zakaria hasil dari gaya hidup dan perlakuan mereka, menjadi sudah tidak manusia lagi, maka implikasinya ialah tamadun yang tercipta dari perlakuan mereka itu juga bukan tamadun manusia. Larangan Islam terhadap kumpulan LGBT jelas, demi mnnjaga dan memelihara manusia dan tamadun manusia. Keutamaan dalam konteks maqasid syariah untuk memelihara agama dan keturunan dengan penekanan kepada maslahah ummah hendaklah menjadi tunjang dalam mendepani ancaman dan cabaran ini.

\section{Daftar Pustaka}

\section{Buku Teks}

Rahman, Afzalur, Islam Ideology and The $W$ ay of Life (Kuala Lumpur: Pustaka Hayathi, 1995).

Haridi, Noor Hafizah bt. Mohd, "Metodologi Dakwah Persatuan Amal Firdausi(PAFI) terhadap kumpulan LGBT", Laporan Geran Penyelidikan KUIS, 2015.

Ibn Manzur, Lisan al-'Arab (Beirut: Dar alTurath al-'Arabi, 1992).

Azmi, Kamal, Abd. Rahman, Profil Masayarakat Melayu Malaysia di Media Sosial Yang Mempromosikan Agenda LGBT dalam IsuIsu Semasa Media dan Dakwah (Kuala Lumpur: Universiti Malaya: 2005).

Kamil, bin Hj Abd.Majid, Cabaran Umat Dewasa Ini: Suatu Penyelesaian Menurut Islam. (Kuala Lumpur: Fakulti Usuluddin Akademi Islam Universiti Malaya, 1988).

Marbawi, Muhammad Idris Abdul Rauf, Kamus Idris Marbawi Arab-Melayu (Kuala Lumpur:Darul Fikir, 2006) 
Hawwa, Sa’id al-Islam (Beirut: Dar al-Shuruq, 1979).

Tim, The Encyclopaedia of Islam New Edition. (Netherland: Reiden E.J.Brill, WileyBlackwell, 1983).

Zakaria, Stapa, Masyarakat Islam dan Isu Semasa (Kuala Lumpur: YADIM, 1994).

\section{Jurnal}

Evans, Nancy J., "The impact of an LGBT Safe Zone Project on Campus Climate", Journal of College Student Development, Vol 1 No. 22. 2002.

Hamdi, Ahmad Zainul, and Dédé Oetomo Tonny, "Tak Pernah Berhenti Bercinta: Studi Tentang Seksualitas Sepuluh ODHIV di Surabaya", Jurnal Gandrung, 1.2, 2010.

Kosciw, Joseph G., et al., "The Effect of Negative School Climate on Academic Outcomes for LGBT Youth and the Role of in-School Supports", Journal of School Violence, 12.1, 2013.

Mastuti, Ratri Endah, Rachmad Djati Winarno, and Lita Widyo Hastuti, "Pembentukan Identitas Orientasi Seksual pada Remaja Gay", Prediksi, 1.2, 2012.

Murtagh, Ben, "Gay, Lesbi And Waria Audiences In Indonesia: Watching Homosexuality on Screen", Indonesia and the Malay World, 39.115, 2011.

Perry N. Halkitis et.al, "The Meanings and The Manifestations of Religion and Spirituality Among Lesbain, Bisexsual and Transgender", Journal Adult Development, 16, 2, 2009.

Rahardjo, Wahyu, "Sikap Akan Respon Terhadap Identitas Sosial Negatif Dan Pengungkapan Orientasi Seks Pada Gay", Jurnal Imiah Psikologi, 1.1, 2011.

Renn, Kristen A., "LGBT and Queer Research In Higher Education: The State and Status of The Field", Educational Researcher, 39.2, 2010.

Noor Hafizah bt. Mohd Haridi \&

Norsaleha bt. Mohd Salleh
"LGBT Student Leaders and Queer Activists: Identities of Lesbian, Gay, Bisexual, Transgender, and Queer Identified College Student Leaders And Activists", Journal of College Student Development, 48.3, 2007.

Rozi, Syafwan, "Tracking on Moderate Muslim in Indonesia", Turast: Jurnal Penelitian dan Pengabdian (e-Journal), 2.1, 2016.

Ryan, Caitlin, et al., "Family Acceptance in Adolescence and the Health of LGBT Young Adults", Journal of Child and Adolescent Psychiatric Nursing , 23.4, 2010.

Veritasia, Mytha Eliva, "Pengungkapan Informasi Privat tentang Identitas Seksual Seorang Gay kepada Orang Lain", Commonline Departemen Komunikasi, 4.2, 2015. 